\title{
Review
}

\section{Author(s): Eli F. Heckscher}

Review by: Eli F. Heckscher

Source: Ekonomisk Tidskrift, Årg. 13, häft 1 (1911), pp. 17-20

\section{Published by: Wiley on behalf of The Scandinavian Journal of Economics}

Stable URL: http://www.jstor.org/stable/3437701

Accessed: 19-06-2016 22:40 UTC

Your use of the JSTOR archive indicates your acceptance of the Terms \& Conditions of Use, available at

http://about.jstor.org/terms

JSTOR is a not-for-profit service that helps scholars, researchers, and students discover, use, and build upon a wide range of content in a trusted digital archive. We use information technology and tools to increase productivity and facilitate new forms of scholarship. For more information about JSTOR, please contact support@jstor.org.

Wiley, The Scandinavian Journal of Economics are collaborating with JSTOR to digitize, preserve and extend access to Ekonomisk Tidskrift 


\section{Litteratur.}

Lawrence R. Dicksee, M. Com., F. C. A., Business Organisation. (Longmans' Commercial Series.) London Igro. 283 sid. 5 shillings.

Litteraturen i affärsföretagets olika ekonomiska frågor är knappast värdig dessa frågors ofantliga betydelse, och verkan häraf gör sig gällande åt alla håll, dels i många affärsmäns teori och praktik, dels i nationalekonomernas behandling af många fundamentala ekonomiska problem, såsom kriserna, kapitalet och koncentrationen. Med detta är ingalunda sagdt, att det saknas litteratur på området. Så t. ex. framväller i Amerika för närvarande en fullkomlig flod af böcker om "business» $i$ alla ordets sammansättningar och aspekter, framför allt om »business success», men denna litteratur har en annan uppgift än den nyss antydda. Dess betydelse är nästan helt och hållet - man kunde säga - affärspedagogisk, den åsyftar att utbilda och stärka de karaktärsdrag en framgăngsrik affärsman bäst behöfver; och i betraktande af det ovanligt svagt utvecklade affärssinnet $i$ Sverige skulle några sådana böcker här vara särdeles välbehöfliga. Ett studium af affärslifvets problem kan man emellertid naturligtvis icke vänta af en sådan litteratur. Däremot ha obestridligen handelshögskolorna både i Tyskland, England och Amerika redan fătt en afsevärd betydelse för verklig forskning på det hithörande området. Den litteratur, som härstammar från de s. k. handelsteknikerna $i$ ämnet, blir visserligen lätt rent teknisk, d. v. s. den sysslar öfvervägande med bokförings- och afskrifningsproblem; men vissa af handelsteknikerna, i Tyskland främst prof. Schmalenbach i Köln, lägga sin undervisning mycket bredare och ge förträffliga bidrag till belysning af affärsverksamhetens ekonomiska problem.

Professor Dicksees lilla arbete tillhör denna senare grupp. Dess ändamål är enligt förordet att »angifva förbindelsen mellan å ena sidan nationalekonomien, penningväsendet, bokföringen och andra abstrakta vetenskaper och praktisk affärsverksamhet å den andra», att »angifva beröringspunkterna mellan akademiska studier och verkligt affärslif, i förhoppning att gifva någon realitet ăt forskarens undersökningar och öfvertyga prak-

Ekonomisk Tidskrift. IgII. Häft. I. 
tikern om att de nämnda vetenskaperna kanske hafva något att lära honom». Författaren är genom sin verksamhet ovanligt väl utrustad för denna uppgift. Han är chef för en ansedd Londonfirma af »Accountants», ett hos oss och äfven i Tyskland okändt yrke, som endast ofullständigt kan ătergifvas med yrkesrevisor; det är en mycket viktig klass af experter på bokföringens organisation och affärsorganisation öfver hufvud, hvilka tillkallas för att angifva linjerna för ett nytt företags organiserande, med ledning af ett företags böcker yttra sig om dess ställning och slutligen vid revision eller konkurs företräda den affärstekniska sakkunskapen. Deras ställning är i många hänseenden parallell med affärsjuristernas för tillträde till deras officiella organisation (medförande titeln F. C. A. ==Fellow of the Institute of Chartered Accountants) fordras en fyraårig utbildning med examen - men de få naturligtvis en mycket mera ingående kännedom om affärsförhållanden än dessa. ${ }^{1}$ Författaren till det nu föreliggande arbetet har under en följd af år utvecklat en omfattande författarverksamhet på handelsteknikens olika områden och blef 1902 Birminghams handelsfakultets förste professor i »Accounting» - utan att därför lämna sin verksamhet i London - samt öfvergick efter några år till Londons statsvetenskapliga högskola (London School of Economics and Political Science), där hans undervisning varit präglad af en endast alltför ovanlig förening af affärsinsikter och vetenskaplig läggning. „Business Organisation» utgör en föreläsningsserie vid högskolan under 1909.

Boken är alltigenom af elementär natur, såsom författaren också med eftertryck betonar. Några väsentliga nya resultat har den därför ej att visa upp, men den ser ofta de ekonomiska problemen frăn en annan synpunkt än nationalekonomens och framställer äfven invecklade förhållanden i ett ovanligt klart, behagligt och genombildadt språk.

Tanken är att i tur och ordning framställa affärsföretagets olika problem. I de två första kapitlen diskuteras företagsformerna, enkla bolag, aktiebolag, kooperativa företag, utan några anmärkningsvärda nya synpunkter. I tredje kapitlet, som gäller kapitalanskaffningen, framhålles särskildt förtjänstfullt nödvändigheten af att kapitalet för alltid tillhör företaget. Den som arbetar med kapital, lånadt frăn en bank på kort tid, bygger på en vulkan, säger förf. (sid. 4I) med en stränghet, som kanske

1 I en reseberättelse till "Die Ältesten der Kaufmannschaft" i Berlin har prof. JASTRow gifvit en mycket läsvärd framställning af de amerikanska "public accountants' " ställning, som är alldeles analog med de engelska kollegernas (Berliner Jahrbuch für Handel und Industrie 1904, I, 445-455). 
ej skulle tilltala alla svenska affärsmän; delvis, men ingalunda helt och hållet, beror skillnaden i omdöme naturligtvis på bankernas olika uppgift i England och andra länder.

I följande fem kapitel beröres företagets inre organisation jämte löneformerna. Här redogöres bl. a. för en del tekniska organisationsfrågor, delvis väl kända, såsom »Follow-up»-systemet, delvis ganska anmärkningsvärda. Af största intresse äro kanske năgra jämförelser mellan engelska och amerikanska förhållanden. Förf. säger, att enmansvälde $i$ engelska företag är ganska sällsynt, i det att företagen antingen äro enkla bolag (Partnerships) eller aktiebolag och i de senare den verkställande direktörens makt alltid är begränsad, medan »the President» i de amerikanska bolagen är på en gång styrelserts ordförande och verkställande direktör samt därför nästan allsmäktig. Förf. gillar det engelska systemet, men hans skäl förefalla ej fullt öfvertygande. ${ }^{1}$

Efter några instuckna kapitel om Londons fondbörs och kreditens organisation, det förra mycket klart och koncist, behandlas företagets egen betalnings- och kreditorganisation i tre kapitel, af hvilka det sista, „Insolvent Debtors' Accounts», kastar mycket ljus öfver behandlingen af insolventa kunder. Däremot är framställningen af kooperationen och vinstandelssystemet lika litet som af lönemetoderna i ett föregående kapitel särskildt öfvertygande eller intressant, ehuru något öfverraskande, i det att förf., efter ett ogillande omdöme om kooperationen, välvilligt upptager vinstandelssystemet. Hvad som väl bör vara hufvudfrågan i afseende på detta, nämligen i hvad mån de anställdas arbete direkt kan påverka vinsten, beröres alls icke.

I ett kapitel (kap. I6) med en något egendomlig titel behandlas företrädesvis frăgan om stora och små företag. Förf. är föga böjd att erkänna storproduktionens ekonomiska öfverlägsenhet; enligt hans mening är den punkt, där produktiviteten upphör att vara tilltagande, ganska snart uppnådd och stora fabriker ofta blott en samling nindre fabriker på ett ställe; hufvudskälet härtill ser han i behofvet och svårigheterna af ett stort kontrollmaskineri, som ej kan minskas under dåliga tider. Dessa synpunkter äro ju ej nya, och man skulle onekligen ha behöft en förklaring till att koncentrationen faktiskt ständigt griper omkring sig. - I sammanhang härmed jämföras fram- och återgående företag, hvarvid framhålles, att de senare arbeta billigare, emedan de tillväxande företagen måste skapa an-

1 Jfr en diskussion af hithörande frågor af prof. Wiedenfeld, Das Persönliche im modernen Unternehmertum, två uppsatser i Schmollers Jahrbuch för I910. 
läggning för en större produktion än de ännu uppnått. Denna i viss mån oväntade synpunkt är naturligtvis riktig $\mathrm{i}$ och för sig, men man vågar nog påstå, att dess verkan till stor del uppväges af det förhållandet, att ett stillastående eller återgående företag amorterar sin anläggning långsammare och därför är hänvisadt till att arbeta med föråldrade maskiner, medan däremot det växande företaget hastigare kan tillgodogöra sig alla tekniska förbättringar.

I två kapitel behandlas sedan på ett utmärkt sätt spekulationens och försäkringens betydelse för ett företag; dock lägges kanske nästan väl stor vikt vid försäkringens preventiva karaktär, med den motivering, att försäkringsbolaget sörjer för att allt gjorts som kan förekomma den händelse försäkringen gäller - mot detta står naturligtvis affärsmannens eget minskade intresse af att själf sörja därför.

I ett slutkapitel behandlas till sist statens ingripande för reglering och kontroll, utan egentligt nya synpunkter, men ganska välvilligt mot statsingripande; större delen af utrymmet ägnas åt frågan om möjligheten att föreskrifva publicering af likformiga berättelser eller räkenskaper.

Tillräckligt torde ha sagts för att visa den lilla skriftens beskaffenhet och värde. Den är väl förtjänt att läsas af både teoretiker och praktiker kanske främst af de senare; om den ej i så öfvervägande grad uppehölle sig vid engelska förhållanden - hvilket den dock gör mindre än engelsk litteratur i allmänhet - skulle man önska den öfversatt till svenska.

Eli F. Heckscher.

ERIK SJÖSTRAND, Centralbankens väsentliga funktioner jämte en kortfattad redogörelse för bankernas funktioner i allmänhet.

Norstedt \& Söner, Sthlm 1910. Kr. 3,50.

Innehållet i denna bok framgår med tillräcklig klarhet af titeln. Det har varit förf:s afsikt att ge en framställning af centralbankernas väsentliga funktioner; hvilka förf. anser dem vara framgår af rubrikerna på hufvudafdelningens tre kapitel: „Centralbankens ställning till kapitalmarknaden; Centralbanken och kreditomloppsmedlen; Centralbankens uppgift med afseende på penningvärdet». För att få en bakgrund härtill behandlar förf. inledningsvis »bankernas funktioner $\mathrm{i}$ allmänhet», särskildt deras inflytande på penningvärdet.

Om sålunda innehållet är lätt att fastställa, känner man sig däremot så mycket mera osäker om hvad förf. egentligen åsyftar med sitt arbete. 